\title{
Relationship Between Compassion Fatigue in Nurses, and Work-Related Stress and the Meaning of Life
}

\author{
Hakime Aslan ${ }^{1} \mathbb{D} \cdot{\text { Behice } \mathrm{Erci}^{2} \cdot \text { Hatice Pekince }}^{3}$ \\ Accepted: 21 November 2020 / Published online: 2 January 2021 \\ (c) Springer Science+Business Media, LLC, part of Springer Nature 2021
}

\begin{abstract}
This research was conducted in order to examine the correlation between workrelated stress and meaning of life in association with compassion fatigue of nurses, as well as to determine the factors that affect compassion fatigue. The research is cross-sectional. The population of the research is comprised of nurses working at a university hospital in the east of Turkey. The research was carried out with 336 nurses. "Introductory information form," "Work-related strain inventory," "Professional quality of life scale and compassion fatigue subscale" and "Life attitude profile" were used for data collection. It was identified that correlation between compassion fatigue and attitude to life profile is negative $\left(r=-.542^{* *}, p=0.000\right)$, while the correlation between work-related stress and compassion fatigue is positive $\left(r=.204^{* *}, p=0.000\right)$. Moreover, it was determined that attitude to life profile, work-related stress, work manner, amount of time working at one occupation, service held and gender have effect on compassion fatigue.
\end{abstract}

Keywords Compassion fatigue $\cdot$ Stress $\cdot$ Meaning of life $\cdot$ Nurse

Hakime Aslan

hakime.aslan@inonu.edu.tr

Behice Erci

behiceerci@hotmail.com

Hatice Pekince

hatturk23@hotmail.com

1 Department of Fundamentals of Nursing, Faculty of Nursing, Inonu University, Malatya 44280, Turkey

2 Department of Public Health Nursing, Faculty of Nursing, Inonu University, Malatya 44280, Turkey

3 Department of Nursing, Firat University, Elazı $\breve{g} 23000$, Turkey 


\section{Introduction}

Nurses are the largest and the most significant professional group in the health sector. They work in an increased workload in the healthcare system in order to meet the complex necessities of patients and are at risk of the compassion fatigue (Smith 2012:1). According to Figley, the compassion fatigue is a cost of caring (Figley 1995). A general expression of compassion fatigue is described as a result of a continuous and intense contact with patients, constantly giving something of themselves and being subjected to a lot of stress, that afterwards turns into a progressive process that manifests as a stress compassion (Coetzee and Klopper 2010).

A compassion fatigue is a natural consequence of witnessing those who are sick, suffering, etc. Apart from that, it is also known as the result of the stress of trying to assist someone who have had a traumatic experience and who is important to the person, and of the desire to help the person who is suffering or traumatized (Şirin and Yurttaş 2015). A compassion fatigue is a statement that measures the level of health worker's burnout. Health workers need to have a sense of compassion toward patients they take care of (Polat and Erdem 2017). However, the feeling of compassion is replaced by compassion fatigue over time, due to the fact that they (health workers) are always there when patients suffer or have a delay in recovery time (Figley 2002). Compassion fatigue seen in health workers causes desensitization to patients and care (Figley 2002).

A compassion fatigue is defined as a feeling resulted in experiencing an event that includes of a work-related stress (Figley 1995). For this reason, it is important to evaluate nurses' work-related stress and tension. According to research works about factors causing stress in nurses, the factors can be sorted as following: patient care, feeling the responsibility for deadly ill, knowledge-skill level, lack of communication between interdisciplinary and multidisciplinary staff members, relationship with management, conditions related to the work environment, role conflict with health team members, lack of social support and increased density of patients (Aylaz and Durmuş 2000; Topuz 2006; Garrosa et al. 2010; Chayu and Kreitler 2011). All of these factors increase the level of stress and tension at nurses.

Nurses' view on the meaning of life may change negatively due to increased compassion fatigue and stress. It is difficult to put meaning of life in one common sense, because the perception of it changes from person to person. Frankl stated that people who still do not understand the meaning of life and think that there's no such thing as purpose in life are aimless and uncertain about their own future (Frankl 2017). On the other hand, Klinger emphasizes that the meaning of life is in importance of mental problems (Klinger 1998). The attempt to find a purpose of life is very individual. For an individual, to find the meaning of life means to find the most appropriate solution to the issues and troubles of life and to fulfill his/her responsibility (Ajit 1998). As long as a person does these, his/her life will start to make sense and his/her mental health will be protected. 


\section{Materials and Methods}

Research Type This research is cross-sectional.

\section{Population-Sampling}

The population of the research includes 957 nurses who work at a university hospital in the East of Turkey. The sample of the study comprised 330 nurses with 0.95 representation power, 0.05 error and 0.95 confidence interval in the power analysis. A simple random sampling method was used to select a sample from the population. The study was conducted with total of 336 nurses. Those who were on leave during the research (49), not meeting research criteria (28) and did not want to participate (65) were excluded from the sample.

\section{Data Collection}

The data were collected by the researcher using face-to-face meetings technique. All the necessary explanations about the research were given in nurse rooms, oral or verbal consents were taken from the nurses. Forms were distributed to the nurses to be filled in a needed time period (10-15 min). Nurses who did not want to take part or were on a leave were excluded from the research. Four separate forms were used as means of data collection. The researcher used for evaluate socio-demographic features of nurses "Introductory information form," and "Work-related strain inventory," "Professional quality of life scale and compassion fatigue subscale" and "Life attitude profile."

\section{Professional Quality of Life Scale (ProQOL)}

This was developed by Hudnall Stamm (Stamm 2005). The scale that works as selfnotification tool of three subscales and 30 items. Those three subscales are compassion satisfaction, burnout and compassion fatigue. The evaluation of items is done upon Likert scale from t "Never (0)" to "Very often (5)", on a 6 points basis. Compassion fatigue subscale was used in this research. The compassion fatigue subscale is a test designed to measure the symptoms that occur as a result of an encounter with a stressful event. Workers who score high on this scale are advised to receive support or assistance. $2,5,7,9,11,13,14,23,25,28$ items on the scale are developed to measure this situation. The adaptation of this scale to Turkish, its validity and reliability was done by Yeşil et al. The Cronbach Alpha value of compassion fatigue subscale is found as 0.80 (Yeşil et al. 2010). The Cronbach Alpha value of compassion fatigue subscale of the current research was found to be 0.83 .

\section{Work-Related Strain Inventory (WRSI)}

Work-related strain inventory is a self-notification Likert type scale which consists of 4 subscales with 18 items. It was developed by Revicki and friends in 1991 with 
an aim to identify work-related stress and tension of healthcare system (Revicki et al. 1991). The lowest score is 18 , the highest one is 72 . The scale doesn't have cut-off values; work-related tension level varies in direct proportion to the score taken from scale. The adaptation of this scale to Turkish, its validity and reliability was done by Aslan and colleagues in 1998 (Aslan et al. 1998). The Cronbach Alpha value of the scale of the current research was found to be 0.74 .

\section{Life Attitude Profile (LAP)}

The validity and reliability of the Life attitude profile scale (life Attitude Profile Revised 'LAP-R'), developed by Reker, in Turkish was made by Erci (2008). Life attitude profile scale is used to evaluate general feelings about the belief that life has a purpose and that events in your life have a meaning at the time when a person faces a life-threatening illness or distressed events (global purpose). The scale developed by Reker has 48 items in it. Cronbach Alpha reliability coefficient of Reker Life attitude profile was determined to be 0.91 (Reker 1981). Since the 18th item had low correlation values, it was excluded from the scale during the validity work done by Erci. In a 7-subscale Likert type scale 7 stand for "absolutely agree" and 1 stands for "absolutely disagree." The Life attitude profile has 4 subscales, those are: Purpose of life, Meaning of life, Choice/Responsibility for life and Research on the meaning of life. If an individual gets high scores from Purpose of life, Meaning of life, Choice/Responsibility for life and Search of the meaning of life scales, it means that he/she has appositive Life attitude profile. The high score at Research on the meaning of life shows the correlation between meaning of life and its meaninglessness. The Cronbach Alpha value of 4 subscales of Erci's study changed between 0.73-0.82, so the Cronbach Alpha value of the scale found to be 0.91 (Erci 2008). The Cronbach Alpha value of the scale of the current research was found to be 0.92 .

\section{Research Variables}

The Dependent Variable Compassion fatigue.

Independent Variables Work-related stress, the meaning of life and demographic variables.

\section{Data Analysis}

The data were analyzed through SPSS 23.0 package software. The suitability of the data to normal distribution was analyzed by Kolmogrov-Smirnov and Shapiro-Wilk tests. It was determined that the data did not match the normal distribution. Weight, mean, standard deviation, Pearson correlation tests and regression analysis were used in a statistical analysis of the research. Statistical significance was accepted as $p<0.05$. 


\section{Ethical Issues of the Research}

Ethical approval for the research was obtained from Scientific Research and Publication Ethics board of a University. In addition, permission was given by Medical Center. Nurses were informed about the study and written or oral consents were obtained from those who agreed to participate.

\section{Findings}

The socio-demographic features of nurses who participated in the research are given in Table 1. The average age of nurses was 33.6 \pm 6.7 years and their duration of work in the profession was $6.7 \pm 3.4$ years. Out of the respondents $81.5 \%$ were female, $71.7 \%$ were married, $72.9 \%$ had bachelor's degree, $69 \%$ were service nurses, $81.2 \%$ worked mixed day and night and $31.5 \%$ served in medical units (Table 1).

The nurses received a score of $14.3 \pm 7.7$ on the compassion fatigue scale and it was seen that they have a low level of compassion fatigue. Stress level was found to be moderate, with a score of $40.8 \pm 6.1$ on the work-related strain inventory. They received a score of $162.3 \pm 20.9$ on the Life attitude profile scale and had a positive outlook on life. It was seen that they scored $42.1 \pm 7.5$ points from the purpose of life subscale, $35.6 \pm 5.8$ points from the meaning of life subscale, $43.5 \pm 7.1$ points from the choice/responsibility of life subscale and $40.9 \pm 4.9$ points from the research on the meaning of life subscale (Table 2).

Looking at the correlation between them, it was seen that a positive correlation between compassion fatigue and work-related stress $(r=0.204, p=0.000)$. It was determined that the relationship between them was in a positive direction at a weak level. In other words, compassion fatigue of nurses increases when work-related stress does. There was a negative correlation between work-related strain and life attitude profile $(r=-0.169 * *, p=0.002)$, and increased tension was found to negatively affect the meaning of life. It was determined that the relationship between them was in a negative direction at a weak level. Moreover, it was determined that there is a negative correlation between compassion fatigue and life attitude profile $(r=-0.542 * *, p=0.000)$, i.e., that attitudes toward life were negatively affected as compassion fatigue increased. It was determined that the relationship between them was in a negative direction at a moderate level (Table 3).

Firstly, it was defined that difference in compassion fatigue scale according to the gender was statistically significant $(p<0.05)$ and that women had a higher level of compassion fatigue. Secondly, the difference in compassion fatigue scale in accordance with marital status was statistically significant $(p<0.05)$ and the level of compassion fatigue was higher in singles. Thirdly, the difference in compassion fatigue scale and educational level was not statistically significant $(p>0.05)$; however, nurses who possess post-graduate degree were found 
Table 1 The socio-demographic features of nurses who participated in the research
Socio-demographic features

Amount

Percentage

Age $33.6 \pm 6.7$

Duration of work in the profession (years) $6.7 \pm 3.4$

Gender

Female

274

81.5

Male

62

18.5

Marital status

Married

Single

241

Education Level

Vocational high school

Associate degree

61

Bachelor's degree

Master's degree

245

Duty at the Clinic

Nurse in charge $\quad 19$

5.7

Unit nurse

69.0

Intensive care nurse

232

25.3

Work Manner

Only daytime

85

18.8

Mixed day and night

63

81.2

Working Unit

Medical unit

Surgical unit

106

26.8

Intensive care unit

Emergency unit

Pediatric unit
18.8

13.4

63

45

9.5

Table 2 Average scores of nurses on compassion fatigue, work-related strain inventory and life attitude profile

\begin{tabular}{lccc}
\hline Scale & $\begin{array}{l}\text { Possible Min-Max } \\
\text { values }\end{array}$ & $\begin{array}{l}\text { Min-Max values taken } \\
\text { from the scale }\end{array}$ & X \pm SS \\
\hline Scale of compassion fatigues & $0.0-50.0$ & $1.0-35.0$ & $14.3 \pm 7.7$ \\
Work-related strain inventory & $18.0-72.0$ & $27.0-88.0$ & $40.8 \pm 6.1$ \\
Life attitude profile & $30.0-210.0$ & $56.0-192.0$ & $162.3 \pm 20.9$ \\
Purpose of life & $8.0-56.0$ & $13.0-55.0$ & $42.1 \pm 7.5$ \\
Meaning of life & $7.0-49.0$ & $12.0-47.0$ & $35.6 \pm 5.8$ \\
Choice/responsibilityof life & $8.0-56.0$ & $19.0-55.0$ & $43.5 \pm 7.1$ \\
Research on meaning of life & $7.0-49.0$ & $12.0-48.0$ & $40.9 \pm 4.9$ \\
\hline
\end{tabular}


Table 3 Correlation between compassion fatigue, workrelated strain and meaning of life

\begin{tabular}{lll}
\hline & $\begin{array}{l}\text { Scale of } \\
\text { compassion } \\
\text { fatigues }\end{array}$ & Life attitude profile \\
\hline Work-related strain inventory & $r=.204 * *$ & $r=-.169 * *$ \\
& $p=.000$ & $p=.002$ \\
Scale of compassion fatigues & & $r=-.542^{* *}$ \\
& & $p=.000$ \\
${ }^{* *} p<0.05$ & &
\end{tabular}

to have a higher level of compassion fatigue. Fourthly, the difference in compassion fatigue scale and work manner as well as working unit was statistically significant $(p<0.05)$, nurses who worked mixed day and night and worked in intensive care were found to have a higher level of compassion fatigue. Lastly, there was a positive correlation between age/ duration of work in the profession and compassion fatigue, and that the difference between them was statistically significant $(p<0.05)$, i.e., compassion fatigue is increasing when the age and working time of nurse increases (Table 4).

Linear regression stepwise model was used to determine the actual factors affecting compassion fatigue. Total of life attitude profile, work-related strain inventory (WRSI), age, gender, marital status, education level, working time, duty at the clinic, work manner and working unit were taken as independent variables. Total score of compassion fatigue was taken as a dependent variable. According to the results of the regression analysis, it was found that the following factors had these much effect magnitudes on compassion fatigue: Life attitude profile total at 0.29 impact size; life attitude profile total and work-related strain total at 0.30 impact size; life attitude profile total, work-related strain total and work manner total at 0.31 impact size; life attitude profile total, work-related strain total, work manner and duration of work in the profession total at 0.33 impact size; life attitude profile total, work-related strain total, work manner, duration of work in the profession and working unit total at 0.33 impact size; life attitude profile total, work-related strain, work manner, duration of work in the profession, working unit and gender at 0.35 impact size, $(p<0.001)$. The effect of qualitative data-dependent characteristics on compassion fatigue has been determined and $R=.594, R^{2} .353$. It was determined that $35.3 \%$ of the total variance in the dependent variable of the compassion fatigue scale was statistically significant $(p<0.001)$ as described by these variables. Total score of the life attitude profile was found to have the greatest impact on compassion fatigue alone. Such variables as age, education level, marital status and duty at the clinic were excluded from the model due to the ineffectiveness on compassion fatigue (Table 5). In the first analysis, it was found that there were significant differences between age and marital status and compassion fatigue, but they were not effective in regression analysis. 
Table 4 Average scores comparison of sociodemographic features of nurses and compassion fatigue
Scale of compassion fatigues $(\mathrm{CF}) \mathrm{X} \pm \mathrm{SD}$

Gender

Female

$14.94 \pm 7.72$

Male

$11.98 \pm 7.50$

Test (t)

2.740

$p$

$0.006 *$

Marital status

Married

$13.04 \pm 7.35$

Single

$15.99 \pm 8.67$

Test (t)

1.346

$p$

$0.023 *$

\section{Education level}

Vocational high school

$12.73 \pm 7.14$

Associate degree

$16.14 \pm 6.10$

Bachelor's degree

$15.53 \pm 7.97$

Master's degree

Test (KW)

$17.88 \pm 7.76$

7.038

$p$

0.071

Duty at the clinic

Nurse in charge

$12.78 \pm 6.10$

Unit nurse

$12.42 \pm 7.33$

Intensive care nurse

$13.25 \pm 7.90$

Test (KW)

8.462

$p$

0.744

Work manner

Only daytime

$12.26 \pm 7.62$

Mixed day and night

$15.89 \pm 7.78$

Test (t)

$-1.775$

$p$

$0.003 *$

\section{Working unit}

Medical unit

$14.83 \pm 8.15$

Surgical unit

$12.96 \pm 8.15$

Intensive care unit

$16.50 \pm 8.46$

Emergency unit

$13.50 \pm 7.50$

Pediatric unit

$11.44 \pm 6.42$

Test (KW)

8.826

$p$

$0.006 *$

Age

$r=.137$

$p=0.032 *$

Duration of work in the profession (years)

$r=.359$

$p=0.000^{*}$

$* p<0.05$ 
Table 5 Examination of the effect of life attitude profile, work-related strain and demographic variables on the compassion fatigue with a regression analysis

\begin{tabular}{|c|c|c|c|c|c|c|c|c|c|}
\hline \multirow[t]{2}{*}{ Model } & \multicolumn{2}{|c|}{$\begin{array}{l}\text { Unstandardized } \\
\text { coefficients }\end{array}$} & \multicolumn{7}{|c|}{ Standardized coefficients } \\
\hline & $B$ & SE & Beta & $T$ & Sig & $F$ & Sig & $R$ & $\begin{array}{l}\text { Adjusted } \\
\text { R square }\end{array}$ \\
\hline 1 (Constant) & 47.011 & 2.789 & & 16.854 & .000 & & & & \\
\hline Life attitude profile total & -.201 & .017 & -.542 & -11.788 & .000 & 138.96 & $.000^{\mathrm{b}}$ & $.542^{\mathrm{a}}$ & .292 \\
\hline 2 (Constant) & 39.866 & 3.984 & & 10.007 & .000 & & & & \\
\hline Life attitude profile total & -.194 & .017 & -.523 & -11.289 & .000 & 73.675 & $.000^{\mathrm{c}}$ & $.554^{\mathrm{b}}$ & .303 \\
\hline Work-related strain total & .146 & .059 & .115 & 2.494 & .013 & & & & \\
\hline 3 (Constant) & 36,538 & 4,200 & & 8,700 & .000 & & & & \\
\hline Life attitude profile total & -.194 & .017 & -.523 & $-11,368$ & .000 & 51.653 & $.000^{\mathrm{d}}$ & $.564^{\mathrm{c}}$ & .312 \\
\hline Work-related strain total & .153 & .058 & .121 & 2.621 & .009 & & & & \\
\hline Work manner & 1.806 & .764 & .107 & 2.363 & .019 & & & & \\
\hline 4 (Constant) & 33,423 & 4.309 & & 7.757 & .000 & & & & \\
\hline Life attitude profile total & -.193 & .017 & -.522 & $-11,464$ & .000 & 41.42 & $.000^{\mathrm{e}}$ & $.578^{\mathrm{d}}$ & .334 \\
\hline Work-related strain total & .137 & .058 & .108 & 2.367 & .019 & & & & \\
\hline Work manner & 2.618 & .812 & .155 & 3.225 & .001 & & & & \\
\hline $\begin{array}{l}\text { Duration of work in the } \\
\text { profession }\end{array}$ & 1.005 & .363 & .134 & 2.765 & .006 & & & & \\
\hline 5 (Constant) & 34.670 & 4.306 & & 8.052 & .000 & & & & \\
\hline Life attitude profile total & -.190 & .017 & -.512 & -11.291 & .000 & & & & \\
\hline Work-related strain total & .123 & .058 & .097 & 2.122 & .035 & & & & \\
\hline Work manner & 2.845 & .811 & .169 & 3,508 & .001 & 34.86 & $.000^{\mathrm{f}}$ & $.588^{\mathrm{e}}$ & .336 \\
\hline $\begin{array}{l}\text { Duration of work in the } \\
\text { profession }\end{array}$ & .954 & .361 & .127 & 2.641 & .009 & & & & \\
\hline Working unit & -.579 & .235 & -.112 & -2.462 & .014 & & & & \\
\hline 6 (Constant) & 36.292 & 4.366 & & 8.313 & .000 & & & & \\
\hline Life attitude profile total & -.185 & .017 & -.501 & -10.991 & .000 & & & & \\
\hline Work-related strain total & .123 & .058 & .097 & 2.141 & .033 & & & & \\
\hline Work manner & 2.757 & .809 & .164 & 3.408 & .001 & 29.94 & $.000^{\mathrm{g}}$ & $.594^{\mathrm{f}}$ & .353 \\
\hline $\begin{array}{l}\text { Duration of work in the } \\
\text { profession }\end{array}$ & .953 & .360 & .127 & 2.650 & .008 & & & & \\
\hline Working unit & -.615 & .235 & -.119 & -2.621 & .009 & & & & \\
\hline Gender & -1765 & .897 & -.088 & -1.968 & .050 & & & & \\
\hline
\end{tabular}

Dependent variable: compassion fatigue total

aPredictors: (constant), life attitude profile total

${ }^{b}$ Predictors: (constant), life attitude profile total, work-related strain total

${ }^{c}$ Predictors: (constant), life attitude profile total, work-related strain total, work manner

${ }^{\mathrm{d}}$ Predictors: (constant), life attitude profile total, work-related strain total, work manner, duration of work in the profession

${ }^{\text {e}}$ Predictors: (constant), life attitude profile total, work-related strain total, work manner, duration of work in the profession, working unit

${ }^{\mathrm{f}}$ Predictors: (constant), life attitude profile total, work-related strain total, work manner, duration of work in the profession, working unit, gender 


\section{Discussion}

Our study identified that nurses scored $14.3 \pm 7.7$ on the compassion fatigue scale and experienced low levels of compassion fatigue, while Kim's research found that nurses experience moderate levels of compassion fatigue (Kim 2013). The results of the research in Turkey showed that the nurses had moderate levels of compassion fatigue (Yeşil et al. 2010; Kara and Çitak 2018; Hür and Ekinci 2018; Arkan et al. 2020). There was a positive correlation between nurses' workrelated stress and compassion fatigue. In the research of Meyer and colleagues, it was found that stress levels increase compassion fatigue, which in turn affects job satisfaction (Meyer et al. 2015). In their study, Meadors and Lamson found that higher frequency of stress in healthcare providers was associated with higher compassion fatigue (Meadors and Lamson 2008). Alongside, nurses' burnout and compassion fatigue levels were associated with anxiety and depression levels as it was found by Hegney and colleagues (Hegney et al. 2014). In the research of Hinderer and colleagues, it was determined that there was a positive relationship between burnout and compassion fatigue (Hinderer et al. 2014). Compassion fatigue is one of the concepts expressed in the concept analysis of prolonged exposure to stress (Jepkins and Warren 2012).

It was determined by this research work that the life attitude profile was the most important factor affecting compassion fatigue and that there was a negative correlation between them. Satisfaction from life is an important factor for maintaining functioning in society (Akdeniz 2014). Recently, with the appearance of positive psychology, the number of studies made on topics such as what will improve a life and how to raise positive features began to increase. Relying on this opinion, if chronic emotional distress acts as a poison in different forms, a number of emotions that are against it can also act as an antidote to this extent. Compassion is one of the concepts that has gained a new place in this field (Akdeniz 2014). In this research, it was determined that those who understood the meaning of life and had a positive outlook on life had less compassion fatigue.

The work manner, duration of work in the profession, the working unit and gender were determined to be the other demographic variables affecting compassion fatigue by regression analysis results $(p<0.001)$. The difference between gender and compassion fatigue was significant $(p<0.05)$ and the women had a higher level of compassion fatigue. Many studies in the literature review have also shown that the difference between gender and compassion fatigue is significant (Yeşil et al. 2010; Mangoulia et al. 2015; Polat and Erdem 2017; Jakimowicz et al. 2018; Seven et al. 2019). It is thought that increased compassion fatigue may have been caused because the vast majority of nurses involved in the study were women and women are more emotional than men.

In this research work, it was identified that nurses working in intensive care experienced more compassion fatigue and that working clinic affected compassion fatigue. Mealer and colleagues found that intensive care unit (ICU) nurses caring for highly complex critical patients had higher levels of traumatic stress than medical and surgical nurses (Mealer et al. 2007). Whereas in another study, a 
significant difference was determined between the working clinic and compassion fatigue level (Arkan et al. 2020). The literature review reports that nurses working in intensive care, emergency, oncology and surgical clinics experience greater compassion fatigue (Potter et al. 2010; Sacco et al. 2015; Jenkins and Warren 2012; Denk 2018). Intensive care units are areas where life-threatening, terminal patients are taken care of. It is believed that increased compassion fatigue is observed during the times of long-term work with patients suffering in these units, long-term stress and frequent experience of patient deaths despite the long and intensive care.

It has been determined that working time in the profession affects compassion fatigue, and compassion fatigue increases as the working time increases. The study by Potter et al. (2010) found that nurses with 11 to 20 years of experience had the highest compassion fatigue (Potter et al. 2010). Working manner was identified as another factor affecting the compassion fatigue. Compassion fatigue of the employees working day and night was found to have a higher level. Denk's research stated that nurses who worked continuously at night had a higher level of compassion fatigue (Denk 2018). It found that working shifts or shifts in pine, or mostly at night, increased exhaustion. Çam mentioned that working shifts or shifts in pine, or mostly at night, increased exhaustion (Çam 2001). The study of Erçevik found that nurses working with a shift (mixed day-night) system had higher burnout levels, desensitization and emotional exhaustion than nurses working during the day (Erçevik, 2010). It is thought that insomnia and fatigue caused by night seizures may have increased compassion fatigue.

\section{Study Limitations}

This research was carried out with nurses working in a single center. Therefore, the results cannot be generalized to the whole universe, this is the limitation of this research. The low rate of participation in the study due to the workload of nurses working in intensive care units is a limitation in this study. Another limitation of the study is that the cluster-weighted modeling is not used according to clinics in selecting the sample from the universe.

\section{Conclusion and Recommendations}

The results of this study showed that nurses had low levels of compassion fatigue, moderate levels of work-related stress and high life attitude profiles. It was determined that with an increased work-related stress compassion fatigue is also increased, and as a consequence, attitude toward life was negatively affected with an increased compassion fatigue. It was defined that gender, duration of work in the profession, work manner and clinical units affect compassion fatigue.

Savvy, empathetic and compassionate nurses are needed to carry out high-quality and humanistic nursing care. In order to protect nurses from compassion fatigue and to ensure that they cope, it is necessary to support them, especially to well 
identify and reduce sources of stress in the work environment. It may be suggested to improve the working conditions of nurses in institutions and to support their personal development through in-service training programs, so as to reduce the stress at work environment.

Acknowledgements The financial support for this study was provided by the investigators themselves.

\section{Compliance with Ethical Standards}

Conflict of interest The authors declare that they have no conflict of interest.

\section{References}

Ajit, K., \& Das. . (1998). Frankl and the realm of meaning. Journal of Humanistic Education \& Development, 36(4), 199.

Akdeniz, S. (2014). Farklı Merhamet Düzeylerine Sahip Üniversite Öğrencilerinde Depresyon, Anksiyete, Stres ve Duygusal Zekânın İncelenmesi (Investigation of depression, anxiety, stress and emotional intelligence in university students with different compassion levels). Doktora Tezi (Doctoral Thesis). Necmettin Erbakan Üniversitesi Eğitim Bilimleri Enstitüsü, Konya.

Arkan, B., Yılmaz, D., \& Düzgün, F. (2020). Determination of Compassion Levels of Nurses Working at a University Hospital. Journal of Religion and Health, 59, 29-39. https://doi.org/10.1007/s1094 3-019-00786-X.

Aslan, S. H., Alparslan, Z. N., Aslan, R. O., Kesepara, C., \& Ünal, M. (1998). İşe bağlı gerginlik ölçeğinin sağlık alanında çalışanlarda geçerlik ve güvenirliği. Düşünen Adam, 11(2), 4-8.

Aylaz R, Durmuş B. (2000). Hemşirelerde iş stresi. 2000'li yıllarda Sağlık Yüksekokullarında Eğitimin Geleceği Sempozyum Kitabı. Malatya: 232-238.

Chayu, T., \& Kreitler, S. (2011). Burnout in nephrology nurses in Israel. Nephrol. Nurs. J, 38, 65-78.

Coetzee, S. K., \& veKlopper, H. C. (2010). Compassion fatigue within nursing practice: A concept analysis. Nursing \& Health Sciences, 12(2), 235-243.

Çam, O. (2001). The burnout in nursing academicians in Turkey. International Journal of Nursing Studies, 38(2), 201-207.

Denk, T., \& Köçkar, Ç. (2018). Bir üniversite hastanesinde çalişan hemşirelerde mesleki yaşam kalitesi merhamet memnuniyeti merhamet yorgunluğu. Hemşirelik Anabilim Dalı, Yüksek Lisans tezi: Gaziantep.

Erçevik, R. (2010). Hemşirelerde işe bağlı gerginlik, tükenmişlik düzeyleri ve etkileyen faktörler. Haliç Üniversitesi Sağlık Bilimleri Enstitüsü Hemşirelik Programı Yüksek Lisans Tezi.

Erci, B. (2008). Meaning in life for patients with cancer: validation of the life attitude profile-revised scale. Journal of Advanced Nursing, 62(6), 704-711.

Figley, C. R. (1995). Compassion fatigue as secondary traumatic stress disorder: An overview. In C. R. Figley (Ed.), Compassion fatigue: Coping with secondary traumatic stress disorder (pp. 1-17). New York: Brunner/Mazel.

Figley, C. R. (2002). Compassion fatigue: psychotherapists' chronic lack of self care. Journal of Clinical Psychology, 58, 1433-1441.

Frankı, V. E. (2017). İnsanın Anlam Arayışı (Çev. Selçuk Budak), Okuyan Us Yayınları, İstanbul.

Garrosa, E., Rainho, C., Moreno-Jimenez, B., \& Monteiro, M. J. (2010). The relationship between job stressors, hardy personality, coping resources and burnout in a sample of nurses: A correlational study at two time points. International Journal of Nursing Studies, 47, 205-215.

Hegney, D. G., Craigie, M., Hemsworth, D., et al. (2014). Compassion satisfaction, compassion fatigue, anxiety, depression and stress in registered nurses in australia: Study 1 results. Journal of Nursing Management, 22(4), 506-518.

Hinderer, K. A., VonRueden, K. T., Friedmann, E., McQuillan, K. A., Gilmore, R., Kramer, B., \& Murray, M. (2014). Burnout, compassion fatigue, compassion satisfaction, and secondary traumatic stress in trauma nurses. Journal of Trauma Nursing, 21(4), 160-169. 
Hür, S., Ekinci, M. (2018). Yoğun Bakım Hemşirelerine Verilen Stres Yönetimi Eğitiminin Merhamet Yorgunluğuna Etkisi. Sağlık Bilimleri Enstitüsü, Psikiyatri Hemşireliği Anabilim Dalı. Doktora Tezi, Erzurum: Atatürk Üniversitesi.

Jakimowicz, S., Perry, L., \& Lewis, J. (2018). Compassion satisfaction and fatigue: A cross sectional survey of Australian intensive care nurses. Aust Crit Care, 31, 396-405.

Jenkins, B., \& Warren, N. A. (2012). Concept analysis: compassion fatigue and effects upon critical care nurses. Crit Care Nurs Q, 35, 388-395.

Kara, D., Çıtak, E.A. (2018). Hemşirelerin Merhamet Yorgunluklarının ve Öz Anlayışlarının İncelenmesi. Sağlık Bilimleri Enstitüsü, Hemşirelik Anabilim Dalı. Yüksek Lisans Tezi, İstanbul: Okan Üniversitesi,

Kim, S. (2013). Compassion fatigue in liver and kidney transplant nurse coordinators: A descriptive research study. Progress in Transplantation, 23(4), 329-335.

Klinger, E. (1998). The search for meaning in evolutionary perspective and its clinical implications. In P. T. P. Wong (Ed.), The human quest for meaning: A handbook of psychological research and clinical applications. Erlbaum: Lawrence Erlbaum Associates Publishers.

Mangoulia, P., Koukia, E., Alevizopoulos, G., Fildissis, G., \& Katostaras, T. (2015). Prevalence of secondary traumatic stress among psychiatric nurses in Greece. Archives of psychiatric nursing, 29(5), 333-338.

Meadors, P., \& Lamson, A. (2008). Compassion fatigue and secondary traumatization: Provider self care on intensive care units for children. Journal of Pediatric Health Care, 35, 303-311.

Mealer, M. L., Shelton, A., Berg, B., Rothbaum, B., \& Moss, M. (2007). Increased prevalence of posttraumatic stress disorder symptoms in critical care nurses. American Journal of Respiratory Critical Care Medicine, 175, 693-697.

Meyer, R. M., Li, A., Klaristenfeld, J., \& Gold, J. I. (2015). Pediatric novice nurses: Examining compassion fatigue as a mediator between stress exposure and compassion satisfaction, burnout And Job satisfaction. Journal of Pediatric Nursing, 30(1), 174-183.

Polat, F. N., \& Erdem, R. (2017). Merhamet yorgunluğu düzeyinin çalışma yaşam kalitesi ile ilişkisi: Sağlık profesyonelleri örneği (The relationship between the level of compassion fatigue and quality of professional life: The case of medical professionals). Süleyman Demirel Üniversitesi Sosyal Bilimler Enstitüsü Dergisi, 26(1), 291-312.

Potter, P., Deshields, T., Divanbeigi, J., et al. (2010). Compassion fatigue and burnout: Prevalence among oncology nurses. Clinical Journal of Oncology Nursing, 14(5), 56-62.

Reker, B., Gary, T., \& Peacock, E. J. (1981). The life attitude profile (lap): A multidimensionol instrument for assesing attitudes toword life. Canadian Journal of Behavioural Science, 13, 264-273.

Revicki, D. A., May, H. J., \& Whitley, T. W. (1991). Reliability and validity of the work related strain inventory among health professionals. Behavioral Medicine, 17, 20.

Sacco, T. L., Ciurzynski, S. M., Harvey, M. E., \& Ingersoll, G. L. (2015). Compassion satisfaction and compassion fatigue among critical care nurses. Critical Care Nurse, 35(4), 32-44.

Seven, A., Doğan, S., Kınık, A., Toraman, K., Daşkın, G., Sevinen, G., \& Doğru, T. (2019). Compassion levels of the intern students of nursing and the influencing factors: Pilot study. OTSBD., 4(3), 273-282.

Smith, P. (2012). Alleviating compassion fatigue before it drags down productivity. Retrieved from http:// www.ltlmagazine.com/article/alleviating-compassion-fatigue-it-dragsdownproductivity.

Stamm BH. (2005). Professional qualitiy of life scale IV tests. Retrieved from http://www.isu.edu/ bhsta $\mathrm{mm}$ /documents/proqol/ProQOL_vIV_English_Oct05.

Şirin, M., \& Yurttaş, A. (2015). Hemşirelik bakiminin bedeli: Merhamet yorgunluğu. Hemşirelik Bakımının Bedeli: Merhamet Yorgunluğu. DEUHFED, 8, 123-130.

Topuz, A. (2006), Hemşirelerde Rol Çatışması Ve Rol Belirsizliği, İş Stresi Ve Aralarındaki İlişkinin Belirlenmesi, Yüksek Lisans Tezi, Cumhuriyet Üniversitesi, Sağlık Bilimleri Enstitüsü, Sivas, (Tez No: 196292).

Yeşil, A., Ergün, Ü., Amasyalı, C., Er, F., Olgun, N. N., \& Aker, A. T. (2010). Çalışanlar için yaşam kalitesi ölçeği türkçe uyarlamasi geçerlik ve güvenilirlik çalişması. Noropsikiatri Arsivi, 47(111-117), 54.

Publisher's Note Springer Nature remains neutral with regard to jurisdictional claims in published maps and institutional affiliations. 